\title{
Evaluation of carbon accrual in afforested agricultural soils
}

\author{
SHERRI J. MORRIS*, SVEN BOHM†, SHAWEL HAILE-MARIAM $\ddagger$ and ELDOR A. PAUL \\ *Biology Department, Bradley University, Peoria, IL 61625, USA, †Kellogg Biological Station, Michigan State University, \\ 3700 East Gull Lake Drive, Hickory Corners, MI 49060, USA, †Irrigated Agricultural Research and Extension Center, \\ Washington State University at Prosser, Prosser, WA 99350, USA, §Natural Resource Ecology Laboratory, \\ Colorado State University, Fort Collins, CO 80523, USA
}

\begin{abstract}
Afforestation of agricultural lands can provide economically and environmentally realistic $\mathrm{C}$ storage to mitigate for elevated $\mathrm{CO}_{2}$ until other actions such as reduced fossil fuel use can be taken. Soil carbon sequestration following afforestation of agricultural land ranges from losses to substantial annual gains. The present understanding of the controlling factors is inadequate for understanding ecosystem dynamics, modeling global change and for policy decision-makers. Our study found that planting agricultural soils to deciduous forests resulted in ecosystem $\mathrm{C}$ accumulations of $2.4 \mathrm{MgC} \mathrm{ha}^{-1} \mathrm{yr}^{-1}$ and soil accumulations of $0.35 \mathrm{MgCha}^{-1} \mathrm{yr}^{-1}$. Planting to conifers showed an average ecosystem sequestration of 2.5 and $0.26 \mathrm{MgCha}^{-1} \mathrm{yr}^{-1}$ in the soils but showed greater field to field variability than when planted to deciduous forest. Path analysis showed that Ca was positively related to soil $C$ accumulations for both conifers and deciduous afforested sites and played a significant role in soil $\mathrm{C}$ accumulations in these sites. Soil $\mathrm{N}$ increases were closely related to $\mathrm{C}$ accumulation and were two times greater than could be explained by system $\mathrm{N}$ inputs from atmospheric deposition and natural sources. Our results suggest that the addition of $\mathrm{Ca}$ to afforested sites, especially conifers, may be an economical means to enhance soil $\mathrm{C}$ sequestration even if it does not result in increasing $\mathrm{C}$ in aboveground pools. The mechanism of $\mathrm{N}$ accumulation in these aggrading stands needs further investigation.
\end{abstract}

Keywords: afforestation, agriculture, carbon sequestration, cations, deciduous forest, land-use change, pine forest, soil nitrogen, soil organic matter

Received 1 June 2006; revised version received 15 January 2007 and accepted 26 November 2006

\section{Introduction}

Soil C pools are a dynamic component of the global C cycle that can be altered by changes in environmental conditions or land management. The evaluation of pool sizes and fluxes, relative to sequestration calculations, requires an understanding of the rates of input and loss from soil systems. It also requires knowledge of the factors controlling soil organic matter (SOM) dynamics. Historically, SOM has provided large contributions to atmospheric $\mathrm{CO}_{2}$ through increased decomposition as a consequence of conversion of native lands to agriculture. The total contributions of $\mathrm{CO}_{2}$ to the atmosphere from land use change were greater than that from fossil

Correspondence: Sherri Morris, tel. +309 677 3016,

fax +309677 3558, e-mail: sjmorris@bradley.edu

(C) 2007 The Authors

Journal compilation (C) 2007 Blackwell Publishing Ltd fuels until nearly 1980 (Houghton et al., 1983). Conversion of currently $\mathrm{C}$-depleted soils to $\mathrm{CO}_{2}$ sinks by afforestation has the potential to mitigate high $\mathrm{CO}_{2}$ levels for a long enough period for other actions to be taken. Sequestering additional soil $\mathrm{C}$ can be achieved through improved management techniques on current agricultural lands and by the transformation of cultivated soils to forest or grassland ecosystems (Guo \& Gifford, 2002; Kimble et al., 2003).

The $\mathrm{C}$ sequestration rates reported for soils following afforestation of agricultural land vary. Post \& Kwon's (2000) review of afforestation research on a global basis suggested that the average increase in soil $\mathrm{C}$ following afforestation was $0.32 \mathrm{MgC} \mathrm{ha}^{-1} \mathrm{yr}^{-1}$, but there was a very large range of accumulation rates for temperate forests ( -0.141 to 0.617$)$. A review of 43 studies, representing multiple countries, by Paul et al. (2002) also 
found variable rates of loss or accumulation, with stands younger than 30 years generally losing $C$ and older than 30 gaining minimal amounts in lower horizons. Guo \& Gifford (2002) used meta-analysis to evaluate the data available from 74 publications across four countries on soil $C$ stocks associated with a number of different types of land use change. Their results suggested that conversion of native forest to pasture may increase soil C stocks likely as a consequence of increased root inputs, however, conversion to plantation or agricultural crops decreases soil C. Returning land use from crop to plantation tended to increase $C$ stocks unless the species planted were pine. Most importantly, their study suggested that processes that altered soil $\mathrm{C}$ stocks could be reversed if the land was returned to its former use. There is also evidence that even without land use change, old growth forests accumulate $C$ in soils under specific conditions (Zhou et al., 2006).

The majority of studies on changes in soil C stocks following land use change have shown relatively small changes to soil C pools, were inconclusive, or showed large gains under a few specific circumstances. Mechanisms for $C$ gain have also been found to vary across sites. Studies have shown increases in aggregation following afforestation to contribute to soil C sequestration (Six et al., 2002). There is also sequestration independent of this mechanism (Del Galdo et al., 2003). There are few solid explanations for the large disparity in results suggesting that our current understanding of C sequestration following afforestation of agricultural land is not adequate (Schöning \& Kögel-Knabner, 2006). Belowground resources and storage capacities can be difficult to measure and are, therefore, poorly understood. Understanding the degree to which soils can act as sinks for atmospheric $\mathrm{CO}_{2}$ necessitates an understanding of both the levels of SOC currently present and the effect of future management and global change such that the $\mathrm{C}$ storage dynamics can be predicted.

Improving sink status of afforested soils requires elucidation of the control mechanisms for $C$ storage in soils. One key mechanism that may control C storage in forest soils is tree type. Pregitzer \& Palik (1997), Richter et al. (1999), Guo \& Gifford (2002), Paul et al. (2002), and Paul et al. (2003) found that afforestation of agricultural land to pine forests resulted in accumulations of $\mathrm{C}$ in aboveground biomass but decreases in soil C. However, other studies have found coniferous native sites to have higher soil $\mathrm{C}$ levels than associated agricultural land (Johnson, 1992; Ellert \& Gregorich, 1996). Hooker \& Compton (2003) found increases in aboveground, litter, and deep soil $(20-70 \mathrm{~cm}) \mathrm{C}$ following afforestation with Pinus strobus, yet with no accumulations in the $0-20 \mathrm{~cm}$ soil layer. Bellamy et al. (2005) found C losses from all soils, suggesting that climate change was already also having an effect on soil $\mathrm{C}$ storage.

Another key, mechanism that may control C storage in forest soils is nutrient availability. Many plantations, established as a consequence of owner abandonment, erosion control, and other forms of land improvement, were likely established without evaluation or improvement of nutrient status. Soil C accumulation is dependent on organic inputs. Plant production and the rate at which those materials become incorporated and stabilized in soils are a consequence of nutrient availability. Nitrogen availability is essential to maintain high photosynthetic rates. It has multiple controls on decomposition and SOM formation (Fog, 1988). Low tissue $\mathrm{C}: \mathrm{N}$ ratios increase cellulose decomposition rates, but available $\mathrm{N}$ can retard the genetic expression of peroxidase enzymes required for the degradation of aromatics such as lignin (Agren et al., 2001). Nitrogen is also a constituent of SOM and is required for the formation of humic components (Haider, 1992). Other nutrients such as soil cations are important for stabilizing SOM, once it is in soil, against loss through microbial acquisition or leaching (Baldock \& Nelson, 2000). The amount of $C$ sequestered depends not only on the maximum capacity of the soil to retain $C$ based on vegetation, climate, and parent material, but also upon the flux into and out of soil pools. Soil C flux is largely dependent on plant net primary productivity and on SOM decomposition rates that are largely consequences of nutrient and environmental limitations.

Many studies have found that site preparation or preplanting management, species composition, and/or site fertility can have interactive effects on SOC dynamics (Johnson, 1992). To evaluate these factors, our research has been designed to compare related sites of differing fertility, soil type, and management history (afforested deciduous, afforested conifer, native deciduous forest, and agricultural fields) to determine both the potential for sequestration and the controls affecting SOM dynamics. The site evaluated in this study is one of an extensive transect of long-term, afforested sites being extensively characterized with physical and biological tests (Six et al., 2002; Paul et al., 2003; Rillig et al., 2003). Its texture, cropping history, and tree growth characteristics make it a near-ideal site for such comparisons. Few studies have conducted the intensive soil, vegetation, bulk density, and soil depth analysis required to evaluate these differences on a landscape basis to determine specific management tools likely to improve $\mathrm{C}$ accrual in afforested soils.

We examined soil $\mathrm{C}$ stocks from an agricultural forest landscape in southern Michigan. Soil C stocks from deciduous and coniferous plantations established on agricultural soils 50-60 years ago were compared with 
soil C stocks from adjacent, present day, native forest sites and agricultural fields. Soil $\mathrm{N}$ and other nutrients were determined so that the controls affecting SOM dynamics could be evaluated. Based on similar agricultural history across our sites, our overall hypothesis was that reestablishing trees on agricultural fields would affect soil C across all sites. We predicted that soil C would increase on all afforested sites when compared to the agricultural site but that different tree species and their associated soil biota would result in different levels of soil C sequestration.

\section{Materials and methods}

The site selected for study was the Fred Russ Forest Experiment Station $\left(42^{\circ} 00^{\prime} \mathrm{N}\right.$ latitude and $85^{\circ} 58^{\prime} \mathrm{W}$ longitude) located in Cass County in southwest Michigan. Russ Forest was planted with mixed species stands of oak, tulip poplar, sugar maple, walnut, elm, catalpa, hickory, and pine in 4.5 ha plots in the mid-1940s. Adjacent to Russ Forest is Newton's Woods, a preserved virgin forest containing 72 ha of native, old-growth hardwoods with both beech-maple and oak-hickory forests. Three afforested deciduous areas, three afforested coniferous areas, three native forest areas, and six agricultural areas adjacent to the forest were chosen for study. To reduce the variability associated with random sampling in forest soils (Zinke, 1962; Finzi et al., 1998; Morris \& Boerner, 1999), maple (Acer sp.), oak (Quercus spp.), and tulip poplar (Liriodendron tulipifera) were the sampling focus in the afforested areas and beech (Fagus americana) and maple in the native forest. The conifer stands sampled were pure stands consisting of either red pine ( $P$. resinosa) or white pine ( $P$. strobus).

The soil of Russ Forest and surrounding agricultural areas is derived from parent material deposited during the Cary substage of the Wisconsin Glaciation (Bowman, 1991). This produced well-drained, loamy soils on outwash plains and moraines with $0-3 \%$ slope. The study area soils were predominantly Oshtemo sandy loam (Coarse-loamy, mixed mesic Typic Hapludalfs) and Kalamazoo loam (Fine-loamy, mixed mesic Typic Hapludalfs). Both soil series are similar; however, Oshtemo soil can exist with or without a fine-loamy Bt horizon. Soil type differences are minimal (Crum \& Collins, 1995). As most sample plots contained representative areas of each soil type, the confounding effects of soil type differences were evaluated by including samples from three agricultural areas on each soil type as our comparison. Both soil types are considered prime farmland in Cass County. Agricultural land use is currently $70 \%$ of available land in this county and farming is the main economic enterprise (Bowman, 1991).
Three deciduous forest stands were sampled in spring 1998. In two of the areas (approximately 37 ha total), tulip poplar and walnut were planted in 1945 followed by planting of red oak, in 1946. Sugar maple was a volunteer in these stands. In the other area (18 ha), white oak was planted in 1943 and sugar maple and tulip poplar were planted in 1944. An average of 53 years growth was used for evaluating $\mathrm{C}$ and $\mathrm{N}$ accumulation on a yearly basis. A P. strobus stand planted in 1966 was sampled in fall 1999 and a P. resinosa stand planted in 1939 and P. strobus stand planted in 1943 were sampled in spring 2000. A mean of 49.7 years was used in calculations for these stands where appropriate. As these stands have such a wide range of ages, rates were also calculated independently for the conifer stands.

Soil cores of known volume were divided into $A p$ or $A$, $B$ and $B / C$ to $C$ horizons (Bowman, 1991). The third horizon sampled that included the $B / C$ and parts of the $C$ horizon was sampled to the depth necessary to bring the entire profile depth sampled to $1 \mathrm{~m}$. In the afforested deciduous and coniferous sites only, the $A p$ was divided into two sections, the first $5 \mathrm{~cm}$ and the rest of the $A p$. Ten soil cores $(4.4 \mathrm{~cm}$ diameter) were taken randomly across the length of the field for each agricultural area and composited to five for $\mathrm{C}$ and $\mathrm{N}$ analyses. In forested stands, adjacent and interspace locations were sampled for each tree species. Two adjacent soil cores (4.4, 5, and $1.9 \mathrm{~cm}$ core diameters in deciduous, coniferous, and native sites, respectively) were taken approximately $0.25 \mathrm{~m}$ from the bases of three trees of each species and two interspace samples were taken between the tree sampled and an adjacent tree (not $<1.5 \mathrm{~m}$ from any tree). These samples were composited arithmetically to one from each location for each tree for $\mathrm{C}$ and $\mathrm{N}$ analyses. This sampling design resulted in the collection of 1020 samples. All samples were returned to the laboratory under refrigeration.

Each soil sample was weighed independently for bulk density determinations. Gravimetric water content was determined on a subsample of each sample before compositing. Soil core volume was used to calculate dry bulk density following corrections for gravimetric water content. The soils for $\mathrm{C}$ and $\mathrm{N}$ analyses were ground to pass a $180 \mu \mathrm{m}$ screen and analyzed by dry combustion in a Carlo Erba CN analyzer (CE Instruments Flash EA1112 Series by ThermoQuest, Milan, Italy) using calibration standards and instrument and soil controls (Robertson et al., 1999; Sollins et al., 1999). Nutrients, cations, and general soil characteristics were analyzed in the soil-testing laboratory at Michigan State University (Brown, 1998). Soils were extracted with $1.0 \mathrm{M}$ $\mathrm{COOCH}_{3} \mathrm{NH}_{4}$ and extractable $\mathrm{Ca}, \mathrm{K}$, and $\mathrm{Mg}$ were determined on an atomic absorption spectrometer (Warncke \& Brown, 1998). Available P was determined using the Bray and Kurtz P-1 Test (Frank et al., 1998). 
Total horizon $\mathrm{C}$ and $\mathrm{N}$, cation and $\mathrm{P}$ contents were calculated using bulk density and horizon depth for each horizon in each area for each tree in each location or for each agricultural area independently. Total profile concentrations were determined by summing horizon contents to the depth of a meter. In forested areas, total area represented by adjacent to tree and interspace locations were determined using data on stand density and tree diameter from the forest inventory for deciduous afforested, coniferous afforested, and native forest stands independently. Total profile concentrations for the forested areas were determined by adjusting values for the area represented. Area adjacent to the tree was determined to be $15.6 \%, 27.0 \%$, and $29.3 \%$ for native, deciduous afforested, and coniferous afforested forests, respectively. Differences in soil weight for each soil profile necessitated adjustments in horizon depth (Ellert \& Gregorich, 1996; Six et al., 2002). Soil depth and bulk density were used to evaluate the amount of soil present in each profile sampled. All profile soil weights were adjusted by correcting the depth of the lowest horizon sampled $(B / C$ or $C$ horizon), hence $C$ and $N$ are represented on the basis of $1.19 \mathrm{Mg}$ soil $\mathrm{m}^{-2}$ per profile depth, which is the lightest (native) soil profile.

Ecosystem $\mathrm{C}$ and $\mathrm{N}$ budgets were calculated using soil $\mathrm{C}$ and $\mathrm{N}$ data obtained as described above, litter $\mathrm{C}$ and $\mathrm{N}$ content, and above- and belowground biomass calculated from data obtained in forest inventories. Two litter samples were collected from each tree at each location at the time of sampling using a $15 \mathrm{~cm}$ diameter collector. Litter was collected at every position sampled in the agricultural areas. All litter was returned to the laboratory where it was dried, weighed, ground and analyzed for $\mathrm{C}$ and $\mathrm{N}$ content.

Estimates of above- and belowground contributions to $\mathrm{C}$ and $\mathrm{N}$ budgets were necessary to evaluate ecosystem-level dynamics. A forest inventory to evaluate stand biomass for each forest type was completed to achieve these goals. Aboveground biomass was determined for each of the forest areas using diameter at breast height $(\mathrm{DBH})$ and height measurements in 10 randomly located plots of $30 \times 5 \mathrm{~m}^{2}$ for each area. Total biomass was determined for each plot, by species, using equations derived for trees in that region (Tritton \& Hornbeck, 1982). These values were corrected using the values of Birdsey (1992) to include the difference between merchantable volume and tree volume ['all above- and belowground portions of all live and dead trees, including the merchantable stem; limbs, tops and cull sections; stump; foliage; bark and rootbark; and course tree roots (greater than $2 \mathrm{~mm}$ )'] necessary for ecosystem estimates of $\mathrm{C}$ storage. As the stands sampled were heterogeneous with regards to tree spe- cies and all species were included in the inventory, the $\mathrm{C}$ value for the north central region derived previously for estimating $C$ storage across United States forest ecosystems was used (Birdsey, 1992). Above- and belowground $\mathrm{C}$ contents from trees were calculated using the biomass determinations described above and conversion factors of $52.1 \% \mathrm{C}$ for conifers and 49.8\% C for deciduous species from Birdsey (1992). Values for biomass $\mathrm{N}$ were similarly obtained. Tree biomass $\mathrm{N}$ for deciduous species was calculated based on a tissue $\mathrm{N}$ content of $0.26 \%$ for aboveground tissues and $0.46 \%$ for roots and biomass $\mathrm{N}$ for conifer species was calculated based on a tissue $\mathrm{N}$ content of $0.19 \%$ for aboveground tissues and $0.36 \%$ for roots (Goodale et al., 2002).

Response variables were analyzed using analysis of variance (PROC MIXED; SAS, 1999, SAS Institute Inc., SAS OnlineDoc ${ }^{\circledR}$, Version 8, Cary, NC, USA). In the rare case where data did not comply with the assumptions of ANOVA, data were transformed using square root or log transformations. Untransformed data are reported in all cases. Where main effects were significant, least square means were used to test difference among land-use types, areas, trees and locations. All significant differences reported are at $P \leq 0.05$.

To evaluate the possible impacts of soil chemistry on soil $\mathrm{C}$, the system of structural modeling and causal analysis referred to as path analysis (Arbuckle \& Wothke, 1999) was performed using AMOS 4.0 (SmallWaters Corporation, Chicago, IL, USA). Path analysis is superior to other multiple regression methods for analyses that involve multiple, covarying environmental variables. Traditional multiple regression models require many degrees of freedom to deal with the interaction terms that occur with covarying environmental variables. The use of a large number of interactions terms in the multiple regression model can produce complex models lacking applicability in the real-world (Arbuckle \& Wothke, 1999). Exploratory path analysis does not require large sample size or a large number of interaction terms because of the manner in which the model is constructed. Patterns of covariance among the putatively 'independent' variables are first evaluated. The path model is then built using these covariance relationships, which allow variables that are not 'independent' to be linked in the analysis. Inclusion of linked variables is based on the strength of the relationship and impact on the resultant model. Exploratory path analysis allows variables to be arranged in hierarchic models that quantify direct and indirect effects of environmental variables. Only models wherein the implied covariances did not differ significantly (chi square statistic $P<0.05$ ) from the sample covariances are presented. 
Table 1 Soil horizon depth, bulk density, C and N content by horizon* and the C:N ratio for four land-use types at the Fred Russ Forest Experiment Station, Newton Woods, and surrounding agricultural fields in Cass County, MI

\begin{tabular}{|c|c|c|c|c|c|c|}
\hline Land-use type & Horizon & Depth $(\mathrm{cm})$ & Bulk density $\left(\mathrm{g} \mathrm{cm}^{-3}\right)$ & Horizon C $\left(\mathrm{Mg} \mathrm{ha}^{-1}\right)$ & Horizon $\mathrm{N}\left(\mathrm{Mg} \mathrm{ha}^{-1}\right)$ & $\mathrm{C}: \mathrm{N}$ ratio \\
\hline Agriculture & $A$ & $23.44(0.75)^{\mathrm{b}}$ & $1.29(0.01)^{\mathrm{c}}$ & $29.20(1.56)^{\mathrm{a}}$ & $2.63(0.12)^{\mathrm{ab}}$ & $11.11(0.22)^{\mathrm{a}}$ \\
\hline Conifer & $A$ & $23.14(1.75)^{\mathrm{b}}$ & $1.40(0.05)^{\mathrm{d}}$ & $40.44(3.52)^{\mathrm{b}}$ & $3.08(0.28)^{\mathrm{b}}$ & $13.21(0.24)^{\mathrm{c}}$ \\
\hline Deciduous & $A$ & $30.62(0.79)^{c}$ & $1.14(0.01)^{\mathrm{b}}$ & $44.43(1.63)^{\mathrm{b}}$ & $3.98(0.14)^{c}$ & $11.23(0.10)^{\mathrm{a}}$ \\
\hline Native & $A$ & $11.04(0.35)^{\mathrm{a}}$ & $0.99(0.02)^{\mathrm{a}}$ & $29.78(2.18)^{\mathrm{a}}$ & $2.49(0.17)^{\mathrm{a}}$ & $11.90(1.18)^{\mathrm{b}}$ \\
\hline Agriculture & $B$ & $34.32(1.47)^{\mathrm{b}}$ & $1.39(0.01)^{\mathrm{a}}$ & $16.64(1.54)^{\mathrm{a}}$ & $1.72(0.13)^{\mathrm{a}}$ & $9.50(0.39)^{\mathrm{a}}$ \\
\hline Conifer & $B$ & $34.91(2.04)^{\mathrm{b}}$ & $1.66(0.02)^{\mathrm{b}}$ & $20.25(3.09)^{\mathrm{a}}$ & $1.98(0.30)^{\mathrm{a}}$ & $10.82(0.67)^{\mathrm{bc}}$ \\
\hline Deciduous & $B$ & $27.39(0.96)^{\mathrm{a}}$ & $1.37(0.02)^{\mathrm{a}}$ & $16.19(1.01)^{\mathrm{a}}$ & $1.72(0.11)^{\mathrm{a}}$ & $9.58(0.32)^{\mathrm{ab}}$ \\
\hline Native & $B$ & $41.70(1.87)^{\mathrm{c}}$ & $1.41(0.02)^{\mathrm{a}}$ & $31.36(2.57)^{\mathrm{b}}$ & $2.83(0.24)^{\mathrm{b}}$ & $11.24(0.35)^{\mathrm{c}}$ \\
\hline Agriculture & C & $27.73(1.70)^{\mathrm{b}}$ & $1.49(0.02)^{\mathrm{b}}$ & $5.93(0.73)^{\mathrm{a}}$ & $0.66(0.07)^{\mathrm{ab}}$ & $9.16(0.59)^{\mathrm{a}}$ \\
\hline Conifer & C & $17.51(3.60)^{\mathrm{a}}$ & $1.64(0.07)^{\mathrm{c}}$ & $3.88(0.78)^{\mathrm{a}}$ & $0.52(0.12)^{\mathrm{a}}$ & $9.69(1.20)^{\mathrm{a}}$ \\
\hline Deciduous & C & $30.99(1.40)^{\mathrm{b}}$ & $1.51(0.02)^{\mathrm{b}}$ & $8.29(0.65)^{\mathrm{b}}$ & $0.96(0.09)^{c}$ & $9.35(0.55)^{\mathrm{a}}$ \\
\hline Native & C & $37.87(1.66)^{c}$ & $1.30(0.03)^{\mathrm{a}}$ & $11.93(1.62)^{\mathrm{c}}$ & $0.88(0.11)^{\mathrm{bc}}$ & $14.08(1.38)^{\mathrm{b}}$ \\
\hline
\end{tabular}

*Horizon depth for $C$ horizon is remaining depth needed to bring profile to 1 meter corrected for profile soil weight.

Values represent mean and standard error with agriculture $N=30$, conifer $N=12$, deciduous $N=27$ and native $N=18$. Within horizon means followed by the same letter did not differ significantly among land-use types $(P<0.05)$.

\section{Results}

The $A$ horizon depth was thinnest in the native forest soils and thickest in the deciduous afforested soils with the opposite pattern in the $B$ horizon (Table 1). Conifers had high bulk density in all horizons relative to the deciduous and native forest sites. Although there were significant differences in the horizon depth and bulk density among managed sites, when bulk density was multiplied by depth the $A$ horizon total soil weight did not differ between the afforested conifer and afforested deciduous sites. On a horizon basis, the afforested sites had greater $A$ horizon $\mathrm{C}$ and $\mathrm{N}$ contents than the native forest or agricultural sites, and the native forest had the greatest $B$ horizon $\mathrm{C}$ and $\mathrm{N}$ contents. Soil $\mathrm{C}: \mathrm{N}$ ratio in the A horizon of the afforested conifer site was significantly greater than for the native site and this site was significantly greater than the afforested deciduous site that did not differ from the agricultural site.

There were significant differences in total profile $C$ and $\mathrm{N}$ among land-use types (Table 2). Native forest soils and afforested soils had significantly greater $\mathrm{C}$ than agricultural soils. Total profile $\mathrm{N}$ differed among all land-use types with afforested deciduous soils having the greatest profile $\mathrm{N}$ followed by native forest, afforested conifer, and the agricultural soils having the lowest profile $\mathrm{N}$. The $\mathrm{C}$ and $\mathrm{N}$ content for each ecosystem compartment, above and belowground biomass, soils and litter can be used to determine total sequestration and rate of sequestration in the afforested area. Aboveground $\mathrm{C}$ did not differ among the three forested land-use types (Table 3). On the agricultural fields, all samples were taken in the spring before planting, which

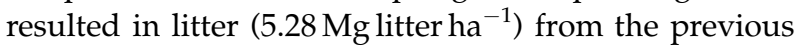

Table 2 Total profile C, N, and CN ratio, to a depth of 1 meter corrected for soil weight, scaled to ha for each area using tree diameter spatial scaling appropriate for land-use type

\begin{tabular}{llll}
\hline & $\begin{array}{l}\mathrm{C} \\
\left(\mathrm{Mg} \mathrm{ha}^{-1}\right)\end{array}$ & $\begin{array}{l}\mathrm{N} \\
\left(\mathrm{Mg} \mathrm{ha}^{-1}\right)\end{array}$ & $\mathrm{C}: \mathrm{N}$ ratio \\
\hline Agriculture & $51.77(2.81)^{\mathrm{a}}$ & $5.01(0.25)^{\mathrm{a}}$ & $10.34(0.27)^{\mathrm{a}}$ \\
Conifer & $64.57(6.79)^{\mathrm{b}}$ & $5.58(0.58)^{\mathrm{ab}}$ & $11.82(0.48)^{\mathrm{b}}$ \\
Deciduous & $70.21(2.54)^{\mathrm{b}}$ & $6.77(0.25)^{\mathrm{c}}$ & $10.42(0.17)^{\mathrm{a}}$ \\
Native & $72.93(3.87)^{\mathrm{b}}$ & $6.20(0.35)^{\mathrm{bc}}$ & $11.85(0.29)^{\mathrm{b}}$ \\
\hline
\end{tabular}

Values represent mean and standard error with agriculture $N=30$, conifer $N=12$, deciduous $N=27$ and native $N=18$. Profile values followed by the same letter did not differ significantly among land-use types $(P<0.05)$.

year's crop being the only biomass present. The amount of litter in the agricultural fields did not differ from the deciduous afforested sites but did differ from the afforested conifer and native in both $\mathrm{C}$ and $\mathrm{N}$ content (Table 3). Litter measurements in the native and deciduous systems do not represent maximal or annual litterfall. They do, however, represent surface $\mathrm{C}$ as the annual litter increment either is currently on the surface or has become part of the measured soil $C$ pool. Total ecosystem $\mathrm{C}$ and $\mathrm{N}$ were greatest in the native forest and lowest in the agricultural sites (Table 3). Afforested sites accumulated an average of $2.36 \mathrm{MgC} \mathrm{ha}^{-1} \mathrm{yr}^{-1}$ in the deciduous afforested and $2.51 \mathrm{Mg} \mathrm{ha}^{-1} \mathrm{yr}^{-1}$ in the conifer afforested sites. Soils accounted for approximately $15 \%$ of the ecosystem $C$ accumulation in this area. In contrast, afforested sites accumulated $0.04 \mathrm{Mg} \mathrm{Nha}^{-1}$ $\mathrm{yr}^{-1}$ in the deciduous afforested and $0.03 \mathrm{Mg} \mathrm{ha}^{-1} \mathrm{yr}^{-1}$ in the conifer afforested sites with soils accumulating 
Table 3 Total C and N ( $\left.\mathrm{Mg} \mathrm{ha}^{-1}\right)$ for each ecosystem component for four land-use types at the Fred Russ Forest Experiment Station, Newton Woods, and surrounding agricultural fields in Cass County, MI

\begin{tabular}{|c|c|c|c|c|}
\hline & Agriculture & $\begin{array}{l}\text { Afforested } \\
\text { deciduous }\end{array}$ & $\begin{array}{l}\text { Afforested } \\
\text { coniferous }\end{array}$ & Native \\
\hline \multicolumn{5}{|l|}{ Ecosystem $C$ stores $\left(\mathrm{Mgha}^{-1}\right)$} \\
\hline Aboveground & - & $93.22^{\mathrm{a}}$ & $87.16^{\mathrm{a}}$ & $145.00^{\mathrm{a}}$ \\
\hline Belowground & 1.1 & 14.16 & 14.52 & 22.03 \\
\hline Litter & $1.41^{\mathrm{a}}$ & $1.80^{\mathrm{ab}}$ & $12.59^{c}$ & $3.29^{\mathrm{b}}$ \\
\hline Soil & $51.77^{\mathrm{a}}$ & $70.21^{\mathrm{b}}$ & $64.57^{\mathrm{b}}$ & $72.93^{\mathrm{b}}$ \\
\hline Total & 54.28 & 179.31 & 178.84 & 243.25 \\
\hline Total accumulation per year & & 2.36 & 2.51 & \\
\hline Soil accumulation per year & & 0.35 & 0.26 & \\
\hline \multicolumn{5}{|l|}{ Ecosystem $\mathrm{N}$ stores $\left(\mathrm{Mg} \mathrm{ha}^{-1}\right)$} \\
\hline Aboveground & - & $0.49^{\mathrm{ab}}$ & $0.32^{\mathrm{a}}$ & $0.76^{\mathrm{b}}$ \\
\hline Belowground & 0.04 & 0.13 & 0.10 & 0.20 \\
\hline Litter & $0.05^{\mathrm{a}}$ & $0.05^{\mathrm{a}}$ & $0.37^{\mathrm{c}}$ & $0.12^{\mathrm{b}}$ \\
\hline Soil & $5.01^{\mathrm{a}}$ & $6.77^{\mathrm{c}}$ & $5.58^{\mathrm{ab}}$ & $6.20^{\mathrm{bc}}$ \\
\hline Total & 5.10 & 7.44 & 6.37 & 7.28 \\
\hline Total accumulation per year & & 0.044 & 0.026 & \\
\hline Soil accumulation per year & & 0.033 & 0.010 & \\
\hline
\end{tabular}

Total accumulations per year were calculated based on 53 years for deciduous and 50 years for conifers. Pool means followed by the same letter did not differ significantly among land-use types $(P<0.05)$.

Table 4 Exchangeable $\mathrm{Ca}, \mathrm{K}, \mathrm{Mg}$, and extractable $\mathrm{P}$ for each area sampled and land-use type means with standard error in parentheses for each stand sampled at four land-use types at the Fred Russ Forest Experiment Station, Newton Woods, and surrounding agricultural fields in Cass County, MI

\begin{tabular}{|c|c|c|c|c|}
\hline Area & Calcium $\left(\mathrm{Mg} \mathrm{ha}^{-1}\right)$ & Potassium $\left(\mathrm{Mg} \mathrm{ha}^{-1}\right)$ & Magnesium $\left(\mathrm{Mg} \mathrm{ha}^{-1}\right)$ & Phosphorous $\left(\mathrm{Mg} \mathrm{ha}^{-1}\right)$ \\
\hline Agriculture & $6.80(0.78)^{\mathrm{c}}$ & $0.79(0.13)^{\mathrm{b}}$ & $1.68(0.2)^{\mathrm{c}}$ & $0.49(0.03)^{\mathrm{a}}$ \\
\hline Conifers & $5.22(1.15)^{\mathrm{bc}}$ & $0.43(0.04)^{\mathrm{a}}$ & $0.68(0.14)^{\mathrm{b}}$ & $0.50(0.10)^{\mathrm{a}}$ \\
\hline Deciduous & $3.13(0.45)^{\mathrm{ab}}$ & $0.38(0.02)^{\mathrm{a}}$ & $0.18(0.04)^{\mathrm{a}}$ & $0.52(0.08)^{\mathrm{a}}$ \\
\hline Native & $1.51(0.26)^{\mathrm{a}}$ & $0.34(0.04)^{\mathrm{a}}$ & $0.19(0.06)^{\mathrm{a}}$ & $0.36(0.05)^{\mathrm{a}}$ \\
\hline
\end{tabular}

Values represent mean and standard error with agriculture $N=12$, conifer $N=9$, deciduous $N=8$ and native $N=9$. Pool means followed by the same letter did not differ significantly among land-use types $(P<0.05)$.

$75 \%$ of the total accumulation in deciduous forests and $40 \%$ in the conifer forests.

Cation content $(\mathrm{Ca}, \mathrm{K}$, and $\mathrm{Mg}$ ) differed significantly among all land-use types while soil $\mathrm{P}$ content did not (Table 4). Agricultural soils had significantly greater $\mathrm{Ca}$, $\mathrm{K}$, and $\mathrm{Mg}$ than forested soils. Within land-use types, there was a wide range of values for cation and $\mathrm{P}$ content among forest sites within a single land-use type and among agricultural fields. Structural analysis was used to evaluate the importance of cations and $\mathrm{P}$ for soil $\mathrm{C}$ status following afforestation. Covariance analysis among cations, $\mathrm{N}$ and $\mathrm{P}$ revealed significant covariance among components tested for deciduous, conifers, and deciduous and conifers together (Table 5). These relationships were used to test the effects on C pool size in afforested deciduous and conifer afforested sites separately (Table 6), and deciduous and conifer sites to- gether (Fig. 1). The analysis for conifer afforestation had a squared multiple correlation of 0.98 indicating that most of the variation in the $\mathrm{C}$ pool size could be explained by cations, $\mathrm{N}$ and $\mathrm{P}$. The analysis for deciduous afforestation had a squared multiple correlation of 0.824 with $\mathrm{N}$ and $\mathrm{Ca}$ as the strongest correlates. The overall relationship for conifers and deciduous species had a squared multiple correlation of 0.97 (Fig. 1) and indicated that overall $\mathrm{C}$ pool size following afforestation at Russ Forest could be predicted based on $\mathrm{Ca}$ and $\mathrm{N}$. The relationship of $\mathrm{N}$ and $\mathrm{Ca}$ to $\mathrm{C}$ pools in afforested deciduous and conifer are further described in Fig. 2. Soil $\mathrm{N}$ and $\mathrm{Ca}$ are significantly positively related to soil $\mathrm{C}$ for deciduous and conifer stands. The range in $\mathrm{N}, \mathrm{Ca}$, and $\mathrm{C}$ contents were much greater for conifer areas (3.36-11.56 $\mathrm{Mg} \mathrm{Nha}^{-1}, \quad 2.27-12.01 \mathrm{MgCa} \mathrm{ha}^{-1}$, and $41.56-151.07 \mathrm{MgCha}^{-1}$ ) than for deciduous areas 
Table 5 Correlation estimates from covariance analysis for afforested sites at the Fred Russ Forest Experiment Station, Cass County, MI, using the structural analysis approach with Amos

\begin{tabular}{lrrr}
\hline & \multicolumn{2}{c}{ Correlation Estimates } & \\
\cline { 2 - 4 } Relationship & Conifer & Deciduous & \multicolumn{1}{c}{ All } \\
\hline $\mathrm{Ca} \leftrightarrow \mathrm{P}$ & $\mathbf{0 . 6 9 9}$ & 0.143 & $-\mathbf{0 . 5 0 2}$ \\
$\mathrm{Ca} \leftrightarrow \mathrm{N}$ & $\mathbf{0 . 7 5 4}$ & 0.505 & $\mathbf{0 . 6 4 5}$ \\
$\mathrm{K} \leftrightarrow \mathrm{P}$ & 0.355 & -0.014 & 0.358 \\
$\mathrm{~K} \leftrightarrow \mathrm{N}$ & 0.259 & 0.495 & 0.287 \\
$\mathrm{~K} \leftrightarrow \mathrm{Ca}$ & -0.043 & $\mathbf{0 . 7 5 5}$ & 0.209 \\
$\mathrm{Mg} \leftrightarrow \mathrm{K}$ & 0.302 & $\mathbf{0 . 7 6 4}$ & 0.423 \\
$\mathrm{Mg} \leftrightarrow \mathrm{N}$ & $\mathbf{0 . 9 4 4}$ & 0.430 & $\mathbf{0 . 6 8 7}$ \\
$\mathrm{Mg} \leftrightarrow \mathrm{P}$ & -0.249 & -0.331 & -0.086 \\
$\mathrm{Mg} \leftrightarrow \mathrm{Ca}$ & $\mathbf{0 . 8 1 4}$ & $\mathbf{0 . 5 3 1}$ & $\mathbf{0 . 8 1 4}$ \\
$\mathrm{P} \leftrightarrow \mathrm{N}$ & -0.153 & $\mathbf{0 . 5 4 5}$ & -0.074 \\
\hline
\end{tabular}

Estimates in bold indicate covariance relationships maintained in overall analysis.

Table 6 Squared multiple correlation (SMC), standardized regression weights and probability for the conifer and afforested sites at the Fred Russ Forest Experiment Station, Cass County, MI, using the Structural Analysis approach of AMOS to evaluate the relationship of total $\mathrm{N}$, exchangeable $\mathrm{Ca}, \mathrm{Mg}, \mathrm{K}$, and extractable $\mathrm{P}$ to total profile $\mathrm{C}$

\begin{tabular}{lrc}
\hline Relationship & Standardized estimate & $P$ value \\
\hline Conifer $S M C=0.986$ & & \\
Profile $C \leftrightarrow \mathrm{Mg}$ & $-\mathbf{0 . 2 9 3}$ & $\mathbf{0 . 0 3 9}$ \\
Profile $\mathrm{C} \leftrightarrow \mathrm{N}$ & $\mathbf{0 . 7 4 1}$ & $\mathbf{0 . 0 0 1}$ \\
Profile $\mathrm{C} \leftrightarrow \mathrm{Ca}$ & $\mathbf{0 . 6 6 0}$ & $\mathbf{0 . 0 0 1}$ \\
Profile $\mathrm{C} \leftrightarrow \mathrm{K}$ & $-\mathbf{0 . 0 9 0}$ & $\mathbf{0 . 0 3 1}$ \\
Profile $\mathrm{C} \leftrightarrow \mathrm{P}$ & 0.176 & 0.073 \\
Deciduous $S M C=0.824$ & & \\
Profile $\mathrm{C} \leftrightarrow \mathrm{Mg}$ & -0.157 & 0.495 \\
Profile $\mathrm{C} \leftrightarrow \mathrm{N}$ & $\mathbf{0 . 7 0 1}$ & $\mathbf{0 . 0 0 1}$ \\
Profile $\mathrm{C} \leftrightarrow \mathrm{Ca}$ & $\mathbf{0 . 5 1 1}$ & $\mathbf{0 . 0 2 5}$ \\
Profile $\mathrm{C} \leftrightarrow \mathrm{K}$ & 0.092 & 0.757 \\
Profile $\mathrm{C} \leftrightarrow \mathrm{P}$ & 0.088 & 0.617 \\
\hline
\end{tabular}

Significant relationships $(P<0.05)$ are in bold.

(5.69-8.23 $\mathrm{MgNha}^{-1}, 1.06-5.41 \mathrm{MgCa} \mathrm{ha}^{-1}$, and 58.2592.04 $\mathrm{MgC} \mathrm{ha}^{-1}$ ).

\section{Discussion}

Storage of $\mathrm{C}$ in soils under deciduous trees at the Russ Forest equaled approximately $18 \mathrm{Mg} \mathrm{ha}^{-1}$ over the 50 years since planting and $13 \mathrm{Mg} \mathrm{ha}^{-1}$ under conifer trees. This is a yearly storage of approximately $0.35 \mathrm{MgC} \mathrm{ha}^{-1}$ $\mathrm{yr}^{-1}$ in the deciduous and $0.26 \mathrm{MgCha}^{-1} \mathrm{yr}^{-1}$ in the

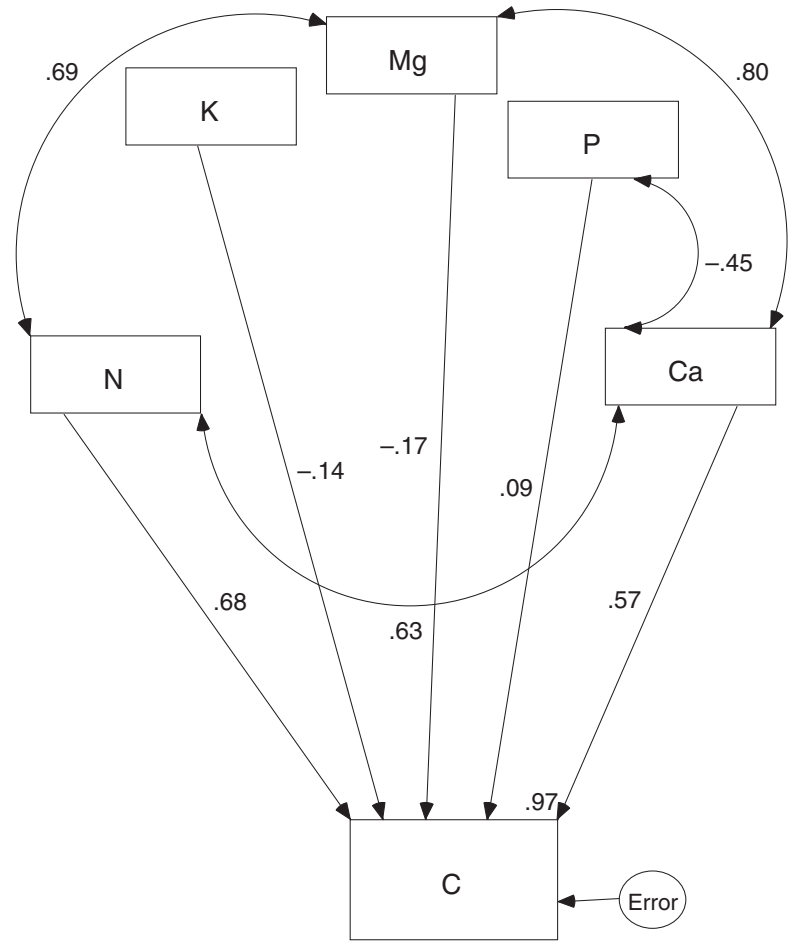

Fig. 1 Structural equation modeling for total organic $C$ in the afforested plots at the Fred Russ Forest Experiment Station, Cass County, MI, including both pine and deciduous forest types. Values on curved lines represent correlations between $\mathrm{N}$, extractable cations $(\mathrm{Mg}, \mathrm{Ca}, \mathrm{K})$ and phosphate $(\mathrm{P})$. Values on straight lines represent standardized regression weights. The squared multiple correlation sits on the top right of the box representing total organic $\mathrm{C}(\mathrm{C})$. The required error component in the model is represented by Error.

conifers, which is similar to the average of $0.32 \mathrm{Mg} \mathrm{ha}^{-1} \mathrm{yr}^{-1}$ found by Post \& Kwon (2000) in their review of $\mathrm{C}$ storage of afforested sites. It is estimated that US agricultural soils can store $75-208 \mathrm{TgC}^{-1}$ through improved management practices (Lal et al., 1998). Land-use change and land restoration are esti-

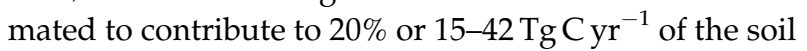
C storage under this model. Williams (1989) reported that a large portion of the 40 Mha of farmland lost in the eastern United States from 1940 reverted to forest vegetation. Extrapolation of the soil $\mathrm{C}$ storage rate from our southern Michigan site to this area would result in storage of $14 \mathrm{TgC}$ in the afforested soils of the eastern United States. Total ecosystem C increased by $118 \mathrm{MgC} \mathrm{ha}^{-1}$ for the afforested area at Russ Forest, a storage of $2.4 \mathrm{MgC} \mathrm{ha}^{-1} \mathrm{yr}^{-1}$ following afforestation. Total ecosystem C storage using Williams (1989) estimate for farmland conversion to forest would result in storage of $96 \mathrm{TgC} \mathrm{yr}^{-1}$ in the eastern US afforested area. This would represent a contribution that is equal to half 

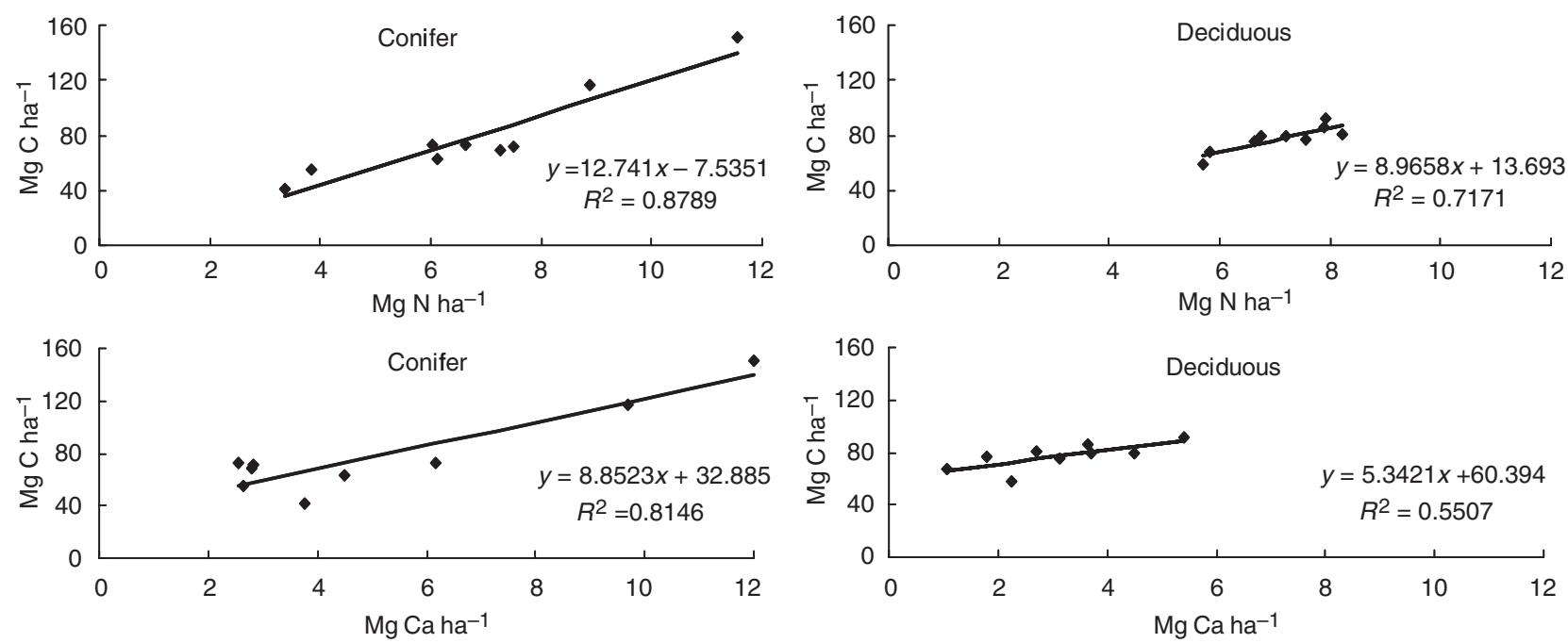

Fig. 2 The relationship of total profile $\mathrm{N}\left(\mathrm{Mgha}^{-1}\right)$ and $\mathrm{Ca}\left(\mathrm{Mg} \mathrm{ha}^{-1}\right)$ to total soil profile $\mathrm{C}\left(\mathrm{Mg} \mathrm{ha}^{-1}\right)$ in afforested deciduous and conifer areas. All relationships were significant at $P<0.05$ and $R^{2}$ and equation representing the linear relationship is presented.

of the predicted $C$ gains through changes in agricultural practices (Lal et al., 1998).

Ecosystem $\mathrm{N}$ also increased in each of the afforested areas studied. It increased from $5.01 \mathrm{Mg} \mathrm{Nha}^{-1}$ in the agricultural fields to 5.58 in the conifers and $6.77 \mathrm{Mg} \mathrm{N} \mathrm{ha}^{-1}$ for the afforested deciduous. The conifers represent an increase of $26 \mathrm{~kg} \mathrm{~N} \mathrm{ha}^{-1} \mathrm{yr}^{-1}$, whereas the deciduous afforested plots increased by $44 \mathrm{~kg} \mathrm{Nha}^{-1} \mathrm{yr}^{-1}$. Average depositional rates of $\mathrm{N}$ were determined for this site using precipitation $\mathrm{N}$ data from the National Atmospheric Deposition Program (NADP) between 1983 and 1998 at the two stations closest to Russ Forest (NADP, 2000). Total yearly inorganic N deposition in precipitation averaged $6.24 \mathrm{~kg} \mathrm{ha}^{-1} \mathrm{yr}^{-1}$, 40 miles southwest of Russ Forest, and $7.06 \mathrm{~kg} \mathrm{ha}^{-1}, 70$ miles northeast of Russ Forest. There was a significant increase in $\mathrm{NH}_{4}^{+}$at the southern site over the last 20 years, and trends suggest that deposition rates at Russ Forest were slightly higher than the southern site. The overall result is that, even taking these patterns into account, the deposition rates are not nearly high enough to explain the large increases in ecosystem $\mathrm{N}$ in these systems. Nonsymbiotic $\mathrm{N}$ fixation likely explains at most $5 \mathrm{~kg} \mathrm{~N} \mathrm{ha}^{-1} \mathrm{yr}^{-1}$ (Knowles \& $\mathrm{O}^{\prime}$ Toole, 1975), suggesting that there is an important source of $\mathrm{N}$ input and mechanism of $\mathrm{N}$ retention operating in the afforested systems that is not operating in the native forest systems.

Nitrogen plays a direct role in $\mathrm{C}$ sequestration and increased $\mathrm{N}$ retention may be increasing $\mathrm{C}$ sequestration potential in terrestrial systems. Melillo (1996) predicted that increased $\mathrm{N}$ deposition would result in an additional $\mathrm{C}$ sequestration of $0.9 \mathrm{PgC}$ for boreal and temperate system forests. This prediction was based on an $\mathrm{N}$ retention efficiency of $100 \%$. Our research suggests the accumulation of $\mathrm{N}$ in the deciduous afforested ecosystem (soils + biomass) at Russ Forest is much greater than can be accounted for by our estimates of wet deposition alone. Estimates of dry deposition in the United States are usually less than wet deposition (Boyer et al., 2002) so even doubling $\mathrm{N}$ deposition rates at this site does not account for $\mathrm{N}$ accrual. This suggests that there is additional $\mathrm{N}$ available to an aggrading system that is not accounted for by total deposition numbers alone, either because local scale $\mathrm{N}$ availabilities differ from broader scale NADP values or because wet deposition cannot be used to adequately predict total wet and dry deposition for a given area. These are important results as the amount $\mathrm{N}$-stimulated C sequestration on deciduous afforested sites is likely a great deal higher than that predicted by Melillo (1996).

There are a number of sources of $\mathrm{N}$ in a predominantly agricultural setting. We found no indication in the available planting records of fertilizer application at time of planting; however, application would have likely balanced removal of available $\mathrm{N}$ by the previous years crop. As there were few obvious contributors to $\mathrm{N}$ fixation in the deciduous vs. coniferous afforested sites, such as $\mathrm{N}$-fixing plants, we postulate that the $\mathrm{N}$ we measured came from absorption of inorganic $\mathrm{N}$ in such forms as ammonium or $\mathrm{NO}_{x}$ from industrial and agricultural atmospheric sources. These data support the findings of Bormann et al. (2002) that suggest unexplained $\mathrm{N}$ additions likely occur, however, Binkley et al. (2000) found few studies that provide data to support 
'occult inputs of $\mathrm{N}^{\prime}$ and suggested that studies that better control for inputs and losses from systems should be undertaken. That our sites currently have greater $\mathrm{N}$ in deciduous afforested sites than adjacent agricultural soils, and significant aboveground biomass was produced over the last 50 years, suggest significant $\mathrm{N}$ inputs. As greater $\mathrm{N}$ retention was detected only in the deciduous afforested soils, these soils likely have a greater overall sequestration potential than the afforested coniferous sites on this landscape. Mechanisms for large amounts of $\mathrm{N}$ accrual should be further investigated on these and other aggrading sites.

The Russ Forest study represents a detailed study of $\mathrm{C}$ and $\mathrm{N}$ storage at a single site. Extensive studies of other sites, using the same methodologies, also showed increases in $\mathrm{N}$ content following land-use change (Paul et al., 2003). At these sites the C:N ratio of the afforested deciduous soils was more similar to that of agricultural fields than that of the adjacent deciduous native site. Nitrogen is required for plant growth and increased residue inputs. It is a constituent of both labile and stable SOM and is required for SOM stabilization. The availability of $\mathrm{N}$ in the soil has been linked to both increased and decreased SOM decomposition rates (Fog, 1988). This is likely a consequence of two factors. First, although available $\mathrm{N}$ will increase cellulose, decomposition it can inhibit lignin decomposition (Boominathan \& Reddy, 1992). Secondly, $\mathrm{N}$ is a component of SOM, which in its humified form can have a C:N ratio of $8: 1$, suggesting $N$ availability will help build stable organic matter (Haider, 1992). Studies that examined $\mathrm{N}$ additions to forest soils suggested that $50-83 \%$ of the $\mathrm{N}$ additions accumulated in the long-term, recalcitrant pool (Magill et al., 1997). There is also a concern that $\mathrm{N}$ saturation may eventually occur in the afforested systems resulting in the ecosystem health problems described in the acid forest soil literature resulting from concomitant soil acidification and $\mathrm{Al}$ solubility problems in areas of excess $\mathrm{N}$ deposition (Aber et al., 1991). Changes to soil C pools across the landscape at Russ Forest are dependent on $\mathrm{N}$ acquisition and on use by plants and microbes. The low C:N ratio of the afforested deciduous site suggests $C$ sequestration will continue; however, long-term additions on the native site may have detrimental long-term effects.

Differences in total profile $\mathrm{C}$ and $\mathrm{N}$ detected among the farms sampled in this study demonstrate that management has large impacts on $\mathrm{C}$ and $\mathrm{N}$ sequestration in agriculture. These differences also impact our $\mathrm{C}$ and $\mathrm{N}$ sequestration estimates for afforestation. We are likely underestimating the amount of $\mathrm{C}$ and $\mathrm{N}$ stored since afforestation. The assumption was made that present agricultural land was representative in SOM contents of the land that was planted in the 1940s. Soil C losses from agriculture have stabilized since the 1960's higher yielding crops, increased plant residue return, and better tillage practices (Flach et al., 1997). It is probable that soil $\mathrm{C}$ and $\mathrm{N}$ contents were lower in all farms in the 1940s when these areas were replanted.

Afforestation of agricultural lands implemented as part of a policy for $\mathrm{C}$ sequestration should increase terrestrial C storage. Agricultural practices alter soils and this historical legacy affects tree establishment and ultimately soil $\mathrm{C}$ sequestration. The agricultural soils in our study had greater cation content than the native or afforested sites. Nutrient status at the time of planting is important for tree growth and may have important consequences for soil C stabilization. On our sites, Ca content varied greatly across the afforested sites. While the conifers appeared to have greater Ca content than the deciduous sites, this reflects the influence of one high Ca stand. It is likely that the Ca content on this site was much larger at the time of tree establishment than on other conifer or deciduous sites.

The relationships of $\mathrm{C}$ to soil cations, $\mathrm{N}$ and $\mathrm{P}$ detected in this study suggest that additions of $\mathrm{Ca}$ even at the moderate levels used in agriculture and fertilizing at time of tree planting can have large impacts on C sequestration. Management recommendations for species and fertility levels should be included as part of policy recommendations to maximize $C$ sequestration. Our data indicate that for areas such as Russ Forest, it should not be necessary to fertilize with N. Deposition and absorption rates for this site should provide ample $\mathrm{N}$ for accrual in biomass. Cation additions, however, may be necessary. Carbon storage in the conifers was particularly sensitive to soil nutrient status and soils with low calcium had low soil C content (Fig. 2). While the relationships detected for conifers were driven by the high Ca site, Paul et al. (2003) also showed strong Ca to $\mathrm{C}$ interactions on a number of other coniferous sites using similar analyses. The afforested deciduous sites also had increases in $\mathrm{C}$ with $\mathrm{Ca}$; however, overall they had more consistent accumulations in $\mathrm{C}$ across sites compared to pines.

While we have detected relationships between $\mathrm{Ca}$ and $\mathrm{C}$, it is not possible to demonstrate causality. There is a great deal of support for the concept that the availability of $\mathrm{Ca}$ in soils alters $\mathrm{C}$ accumulation and stabilization. The role of $\mathrm{Ca}$ in ecosystem dynamics and soil C storage and turnover (Fig. 3) has long been discussed in classic soils literature (Jenny, 1941; Kononova, 1966). More recent work on SOM dynamics (Baldock \& Nelson, 2000; Clough \& Skjemstad, 2000) further highlight, the importance of $\mathrm{Ca}$ in stabilization of SOM. Reich et al. (2005) demonstrated that tree species differentially affect soil Ca content through 


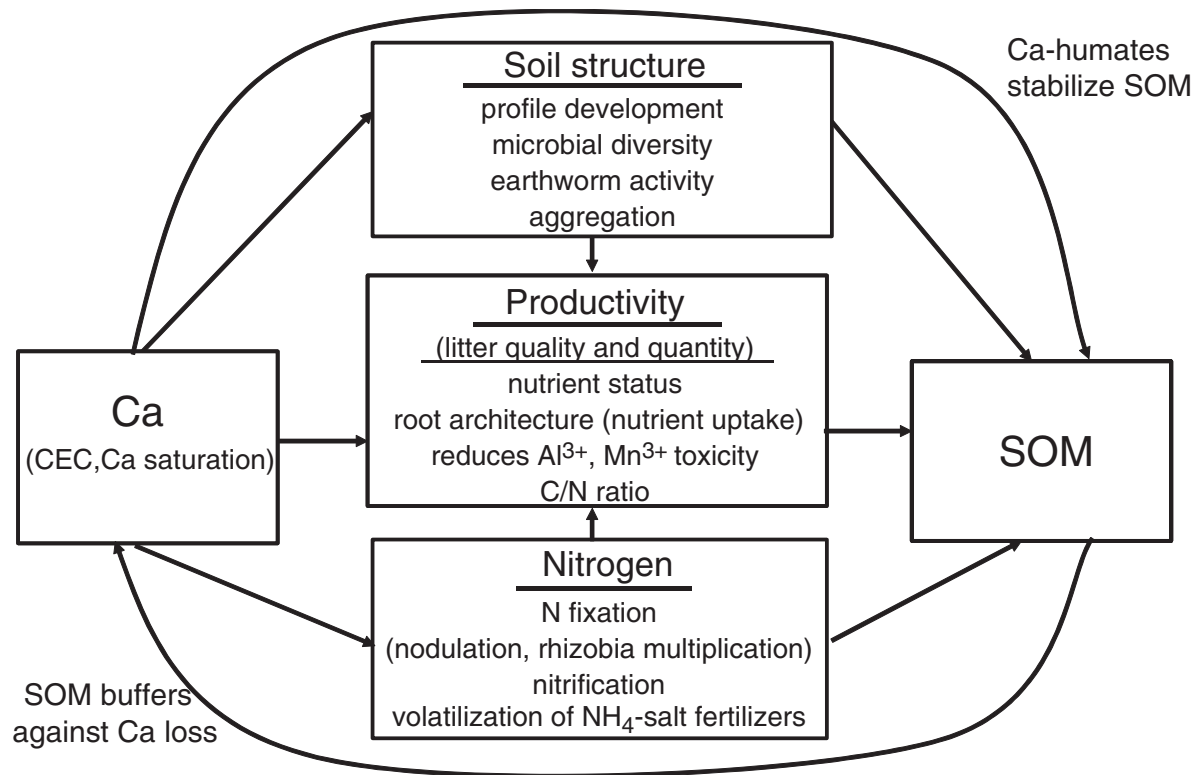

Fig. 3 The role that Ca plays in controlling ecosystem functioning.

differences in litter $\mathrm{Ca}$ and these differences are apparent within 30 years of tree establishment. Calcium is therefore important to include in management strategies designed for forest plantations on disturbed soil systems. A literature review of 18 experiments with $\mathrm{Ca}$ additions of $5-10$ ton $\mathrm{CaCO}_{3} \mathrm{ha}^{-1}$ (Popovic \& Andersson, 1984) showed a general decline in aboveground tree growth during the initial 10-15 years after liming with slight (non-significant) increases thereafter. Liming caused more root growth but less mycorrhizal abundance in the humus layer. This was thought to possibly decrease tree growth due to enhanced moisture stress during dry periods. (Persson, 1988a). Further experiments on the biology of liming (Persson, 1988b) found greater $\mathrm{N}$ immobilization in needle litter materials with liming. It was suggested that increased $\mathrm{N}$ was incorporated into $\mathrm{SOM}$ either as $\mathrm{NH}_{3}$ or as $\mathrm{N}$-rich microbial products that also stabilized soil $\mathrm{C}$.

Afforestation of agricultural soils can provide a very large sink for atmospheric $\mathrm{CO}_{2}$, both in the vegetation and in the soil. Good estimates of soil $\mathrm{C}$ change resulting from afforestation are difficult to acquire and necessitate an understanding of the changes that land-use change has on the ecosystems studied. Agriculture alters bulk density, horizon depth, and movement of $\mathrm{C}, \mathrm{N}$, cations and $\mathrm{P}$ throughout the soil profile. Understanding changes in soil $\mathrm{C}$ dynamics with land-use change requires an incorporation of bulk density and horizon depth information and requires reporting values on an aerial basis to depth. Reporting $\mathrm{C}$ and $\mathrm{N}$ changes without incorporating this essential informa- tion will obscure real changes in ecosystem dynamics. Extrapolating from our site to estimate $\mathrm{C}$ accrual in the eastern deciduous region is not as valuable as the identification of the key controls on $\mathrm{C}$ accumulation in these sites. Evaluating key controllers of $\mathrm{C}$ dynamics and estimating both the total greenhouse gas balance and the economics following land-use change are essential for determining the benefits of afforestation for policy decisions.

\section{Acknowledgements}

This research was supported by the Office of Science (BER), US Department of Energy Grant: Ecosystem Controls on C \& N Sequestration Following Afforestation of Agricultural Soils (DE-FGO2-04ER63890), awarded to Colorado State University with a subcontract to Bradley University. Initial work was conducted under Office of Science (BER), US Department of Energy Grant (DE-FGO3-01ER63183). We would like to thank Greg Kowalewski, Resident Forester of W.K. Kellogg Experimental Forest and Fred Russ Forest Experiment Station, for help with all aspects of this project including the many hours spent in the field assisting with biomass data collection.

\section{References}

Aber JD, Melillo JM, Nadelhoffer KJ, Pastor J, Boone RD (1991) Factors controlling nitrogen cycling and nitrogen saturation in northern temperate forest ecosystems. Ecological Applications, 1, 303-315.

Agren GI, Bosatta E, Magill AH (2001) Combining theory and experiment to understand effects of inorganic nitrogen on litter decomposition. Oecologia, 128, 94-98. 
Arbuckle JL, Wothke W (1999) Amos 4.0 Users Guide. SmallWaters Corp, Chicago, IL.

Baldock JA, Nelson PN (2000) Soil organic matter. In: Handbook of Soil Science (ed Sumner MK), pp. B25-B84. CRC Press, Boca Raton, FL.

Bellamy PH, Loveland PJ, Bradley RI, Lark RM, Kirk JD (2005) Carbon losses from all soils across England and Wales 19782003. Nature, 437, 245-248.

Binkley D, Son Y, Valentine DW (2000) Do forests receive occult inputs of nitrogen? Ecosystems, 3, 321-331.

Birdsey RA (1992) Carbon storage and accumulation in United States forest ecosystems. General technical report WO-59. United States Department of Agriculture. Northeastern Forest Experiment Station, Radnor, PA.

Boominathan K, Reddy CA (1992) Fungal degradation of lignin: biotechnological applications. In: Handbook of Applied Mycology 4. Fungal Biotechnology (eds Arora DK, Elander RP, Mukerji KG), pp. 763-822. Marcel Dekker, New York.

Bormann BT, Keller CK, Wang D, Bormann FH (2002) Lessons from the sandbox: is unexplained nitrogen real? Ecosystems, 5, 727-733.

Bowman WL (1991) Soil Survey of Cass County, Michigan. United States Department of Agriculture. Soil Conservation Service. National Cooperative Soil Survey, Washington, DC.

Boyer EW, Goodale CL, Jaworski NA, Howarth RW (2002) Anthropogenic nitrogen sources and relationships to riverine nitrogen export in the Northeasthern USA. Biogeochemistry, 57, 137-169.

Brown JR (ed) (1998) Recommended Chemical Soil Test Procedures for the North Central Region. Missouri Agricultural Experiment Station SB1001, North central regional research publication No. 221 (Revised), 72 pp.

Clough A, Skjemstad JO (2000) Physical and chemical protection of soil organic carbon in three agricultural soils with different contents of calcium carbonate. Australian Journal of Soil Research, 38, 1005-1016.

Crum JR, Collins HP (1995) KBS Soils. http://lter.kbs.msu.edu/ Soil/Characterization/

Del Galdo I, Six J, Peressotti A, Cotrufo MF (2003) Assessing the impact of land-use change on soil $\mathrm{C}$ sequestration in agricultural soils by means of organic matter fractionation and stable C isotopes. Global Change Biology, 9, 1204-1213.

Ellert BH, Gregorich EG (1996) Storage of carbon, nitrogen, and phosphorus in cultivated and adjacent forested soils of Ontario. Soil Science, 161, 587-603.

Finzi AC, Van Breemen N, Canham CD (1998) Canopy tree-soil interactions within temperate forests: species effects on soil carbon and nitrogen. Ecological Applications, 8, 440-446.

Flach KW, Barnwell TO Jr, Crosson P (1997) Impacts of agriculture on atmospheric carbon dioxide. In: Soil Organic Matter in Temperate Agroecosystems: Long-Term Experiments in North America (eds Paul EA, Paustian K, Elliott ET, Cole CV), pp. 3-13. CRC Press, Boca Raton, FL.

Fog K (1988) The effect of added nitrogen on the rate of decomposition of organic matter. Biology Reviews, 63, 433-462.

Frank K, Beegle D, Denning J (1998) Phosphorus. In: Recommended Chemical Soil Test Procedures for the North Central Region (ed. Brown JR), pp. 21-30. North central regional research publication No. 221 (Revised). Missouri Agricultural Experiment Station, Columbia, MO.

Goodale CL, Lajtha K, Nadelhoffer KJ, Boyer EW, Jaworski NA (2002) Forest nitrogen sinks in large eastern US watersheds: estimates from forest inventory and an ecosystem model. Biogeochemistry, 57/58, 239-266.

Guo LB, Gifford RM (2002) Soil carbon stocks and land use change: a meta analysis. Global Change Biology, 8, 345-360.

Haider K (1992) Problems related to the humification processes in soils of temperate climates. In: Soil Biochemistry, Vol. 7 (eds Stotzky G, Bollag JM), pp. 55-94. Marcel Dekker, New York.

Hooker TD, Compton JE (2003) Forest ecosystem carbon and nitrogen accumulation during the first century after agricultural abandonment. Ecological Applications, 13, 299-313.

Houghton RA, Hobbie JE, Melillo JM, Moore B, Peterson BJ, Shaver GR, Woodwell GM (1983) Changes in the carbon content of terrestrial biota and soils between 1860 and 1980: a net release of $\mathrm{CO}_{2}$ to the atmosphere. Ecological Monographs, 53, 235-262.

Jenny J (1941) Factors of Soil Formation. McGraw-Hill, New York. Johnson DW (1992) Effects of forest management on soil carbon storage. Water Air and Soil Pollution, 64, 83-120.

Kimble JM, Heath LS, Birdsey RA, Lal R (eds) (2003) The Potential of US Forest Soils to Sequester Carbon and Mitigate the Greenhouse Effect. CRC Press LLC, Boca Raton, FL.

Knowles R, O'Toole P (1975) Acetylene-reduction assay at ambient $\mathrm{PO}_{2}$ of field and forest soils: laboratory and field core studies. In: Nitrogen Fixation by Free-living Micro-organisms (ed. Stewart WDP), pp. 285-294. Cambridge University Press, Cambridge.

Kononova MM (1966) Soil Organic Matter: Its Nature. Its Role in Soil Formation and in Soil Fertility, 2nd ed. Pergammon Press, Oxford, UK.

Lal R, Kimble JM, Follett RF, Cole CV (1998) The Potential of US Cropland to Sequester Carbon and Mitigate the Greenhouse Effect. Ann Arbor Press, Chelsea, MI.

Magill AH, Aber JD, Hendricks JJ, Bowden RD, Melillo JM, Steudler PA (1997) Biochemical responses of forest ecosystems to simulated chronic nitrogen deposition. Ecological Applications, 7, 402-415.

Melillo JM (1996) Carbon and nitrogen interactions in the terrestrial biosphere: anthropogenic effects. In: Global Change and Terrestrial Ecosystems (eds Walker B, Steffen W), pp. 431-450. Cambridge University Press, Cambridge, NY.

Morris SJ, Boerner REJ (1999) Spatial distribution of fungal and bacterial biomass in southern Ohio hardwood forest soils in southern Ohio: scale dependency and landscape patterns. Soil Biology and Biochemistry, 31, 887-902.

NADP/NTN (2000) http://nadp.sws.uiuc.edu/

Paul EA, Morris SJ, Six J, Paustian K, Gregorich E (2003) Determination of the controls on carbon and nitrogen dynamics in agricultural and afforested soils. Soil Science Society of America Journal, 67, 1620-1628.

Paul KI, Polglase PJ, Nyakuengama JG, Khanna PK (2002) Change in soil carbon following afforestation. Forest Ecology Management, 168, 241-257.

Persson H (1988a) Effects of liming on root growth. In: Liming as a Measure to Improve Soil and Tree Conditions in Areas Affected by Air Pollution. Results and Experiences of an Ongoing Research 
Programme. National Swedish Environmental Protection Board Report 3518 (eds Andersson F, Persson T), pp. 71-75. Skogsvitalisering Naturvårdsverkt, Solna, Sweden.

Persson T (1988b) Effects of liming on soil biology. In: Liming as a Measure to Improve Soil and Tree Conditions in Areas Affected by Air Pollution. Results and Experiences of an Ongoing Research Programme. National Swedish Environmental Protection Board Report 3518 (eds Andersson F, Persson T), pp. 53-70. Skogsvitalisering Naturvårdsverkt, Solna, Sweden.

Popovic B, Andersson F (1984) Markkalkning och skogsproduktion: litteraturöversikt och revision av svenska kalkningsförsök. Swedish Environmental Protection. Agency, Stockholm. SNV PM 1792, 109 pp.

Post WM, Kwon KC (2000) Soil carbon sequestration and landuse change: processes and potential. Global Change Biology, 6, 317-327.

Pregitzer KS, Palik BJ (1997) Changes in ecosystem carbon 46 years after establishing red pine (Pinus resinosa Ait.) on abandoned agricultural land in the Great Lakes region. In: Soil Organic Matter in Temperate Agroecosystems: Long-Term Experiments in North America (eds Paul EA, Paustian K, Elliott ET, Cole CV), pp. 263-272. CRC Press, Boca Raton, FL.

Reich PB, Oleksyn J, Modrzynski J et al. (2005) Linking litter calcium, earthworms and soil properties: a common garden test with 14 tree species. Ecology Letters, 8, 811-818.

Richter DD, Markewitz D, Trumbore SE, Wells CG (1999) Rapid accumulation and turnover of soil carbon in a re-establishing forest. Nature, 400, 56-58.

Rillig MC, Ramsey PW, Morris SJ, Paul EA (2003) Glomalin, an arbuscular-mycorrhizal fungal soil protein, responds to landuse change. Plant Soil, 253, 293-299.

Robertson GP, Wedin E, Groffman PM, Blair JM, Holland EA, Nadelhoffer KJ, Harris D (1999) Soil carbon and nitrogen availability: nitrogen mineralization, nitrification and soil respiration potentials. In: Standard Soil Methods for Long-term Ecological Research (eds Robertson GP, Coleman DC, Bledsoe CS, Sollins P), pp. 258-271. Oxford University Press, New York.

Schöning I, Kögel-Knabner I (2006) Chemical composition of young and old carbon pools throughout Cambisol and Luvisol profiles under forests. Soil Biology and Biochemistry, 38, 24112434.

Six J, Callewaert P, Lenders S et al. (2002) Measuring and understanding carbon storage in afforested soils by physical fractionation. Soil Science Society of America Journal, 66, 1981-1987.

Sollins P, Glassman C, Paul EA, Swanston C, Lajtha K, Heil JW, Elliott ET (1999) Soil carbon and nitrogen: pools and fractions. In: Standard Soil Methods for Long-term Ecological Research (eds Robertson GP, Coleman DC, Bledsoe CS, Sollins P), pp. 89-105. Oxford University Press, New York.

Tritton LM, Hornbeck JW (1982) Biomass equations for major tree species of the northeast. USDA Forest Service General Technical Report NE-69. Broomall, PA, 46 pp.

Warncke D, Brown JR (1998) Potassium and other basic cations. In: Recommended Chemical Soil Test Procedures for the North Central Region (ed. Brown JR), pp. 31-34. North central regional research publication No. 221 (Revised). Missouri Agricultural Experiment Station, Columbia, MO.

Williams M (1989) Americans and Their Forests: A Historical Geography. Cambridge University Press, Cambridge, NY.

Zhou G, Lui S, Li Z, Zhang D, Tang X, Zhou C, Yan J, Mo J (2006) Old growth forests can accumulate carbon in soils. Science, 314, 1417-1418.

Zinke PJ (1962) The pattern of influence of individual forest trees on soil properties. Ecology, 43, 130-133. 